\title{
Primary Pulmonary Extranodal Marginal Zone Lymphoma: An Atypical Radiological Pattern
}

\section{Primer Pulmoner Ekstranodal Marjinal Zon Lenfoma: Atipik Radyolojik Görünüm}

Pınar Akın Kabalak', Miraç Öz' Özlem Özdemir Kumbasar ${ }^{1}$

\section{Abstract}

Primary pulmonary extranodal marginal zone lymphoma (PPEMZL) arising from the mucosa-associated lymphoid tissue of the bronchus is a very rare disorder. It appears in the form of a slowly progressing localized mass or consolidation. Clinical presentation may include non-specific pulmonary symptoms, such as chronic cough, or dyspnea, but it is more often diagnosed incidentally. Computed tomography (CT) the thorax revealed that the present patient had a giant cystic lesion, parenchymal nodules, and consolidation area. The patient was symptomatic and diagnosed as marginal zone lymphoma by immunohistochemical study of the transthoracic biopsy specimen. This patient is thought to be the first diagnosed as PPEMZL from a cystic lesion.

Key words: Cystic lesion, immunohistochemical staining, pulmonary lymphoma, marginal zone.
Özet

Bronşa ait mukoza ilişkili lenfoid dokudan kaynaklanan primer pulmoner ekstranodal mariinal zon lenfoma nadir görülmektedir. Yavaş progrese olan lokalize kitle ya da konsolidasyon olarak ortaya çıkar. Kronik öksürük, dispne gibi non-spesifik pulmoner semptomlar olabilir ama sıklıkla tesadüfen tanı alır. Hastamiza ait toraks tomografisinde dev kistik bir lezyon ve eşlik eden konsolidasyon ve nodüller vardı. Transtorasik akciğer biopsisi ve immünhistokimayasal inceleme ile marjinal zon lenfoma tanısı elde edildi. Dev kistik lezyon ile radyolojik bulgu veren ilk olgu olarak sunmayı amaçladık.

Anahtar Sözcükler: Kistik lezyon, immünhistokimyasal boyama, pulmoner lenfoma, mariinal zon.
Extranodal lymphomas constitute $3 \%$ to $5 \%$ of all lymphomas and are most frequently observed in the gastrointestinal tract. Primary pulmonary nonHodgkin's lymphoma (NHL) is a very rare disease and accounts for only $0.4 \%$ of all malignant lymphomas (1). Most primary lymphomas of the lung arise from the mucosa-associated lymphoid tissue (MALT) of the bronchus. Pulmonary marginal zone lymphoma (P-MZL) is a disease that arises from bronchial-associated lymphoid tissue; it is the most common subtype of pulmonary NHL.

\footnotetext{
'Department of Chest Disease, Ankara University, Faculty of Medicine, Ankara, Turkey

${ }^{2}$ Department of Pathology, Ankara University, Faculty of Medicine, Ankara, Turkey

${ }^{3}$ Department of Radiology, Ankara University, Faculty of Medicine, Ankara, Turkey

${ }^{4}$ Department of Hematology, Ankara University, Faculty of Medicine, Ankara, Turkey

'Ankara Üniversitesi Tıp Fakültesi, Göğüs Hastalıkları Anabilim Dalı, Ankara

${ }^{2}$ Ankara Üniversitesi Tıp Fakültesi, Patoloji Anabilim Dalı, Ankara

${ }^{3}$ Ankara Üniversitesi Tıp Fakültesi, Radyoloji Anabilim Dalı, Ankara

${ }^{4}$ Ankara Üniversitesi Tıp Fakültesi, Hematoloji Anabilim Dalı, Ankara
}

Submitted (Başvuru tarihi): 25.02.2017 Accepted (Kabul tarihi): 17.03.2017

Correspondence (iletișim): Pınar Akın Kabalak, Department of Chest Disease, Ankara University, Faculty of Medicine, Ankara, Turkey

e-mail: pinarakinn@yahoo.com 
Because of its very rare occurrence, there is no typical radiological pattern for pulmonary MZL. Half of patients are asymptomatic and the pulmonary lesion may be found incidentally. Patients may also have nonspecific pulmonary symptoms, like dyspnea, cough, or hemoptysis. Laboratory findings are usually normal and immunohistochemical staining $(\mathrm{IHS})$ is essential for certain diagnosis (2). The diagnosis is based on histopathological investigation on specimens obtained by surgically or using bronchoscopic methods. Lymphoid cell proliferation on a small specimen is not enough to distinguish malign process from benign lymphoid proliferation. Hence, IHS is essential (3).

\section{CASE}

A 51 -year-old male patient presented with chest pain and cough. His physical examination was normal. Laboratory studies revealed a normal complete blood count and serum biochemistry. The erythrocyte sedimentation rate was $58 \mathrm{~mm} /$ hour. Chest radiograph showed perihilar consolidation in the right hemithorax and cystic lesion in the middle zone of the left hemithorax (Figure 1). CT image of the thorax revealed bilateral multifocal consolidations and cystic lesions (Figure 2). Bronchoscopy was performed and no endobronchial lesion was observed. The smear and culture of bronchial lavage were negative for any microorganism or acid-fast bacilli. Cytological examination of bronchial lavage was also negative for malignancy. Positron emission tomography-CT revealed pathological 18- fluorine fluorodeoxyglucose uptake at the consolidation area and solid component of cystic lesion in the left upper lobe with maximum standardized uptake value of 4.7. CT-guided transthoracic fine needle aspiration was performed and cytopathological examination was suspicious for a lymphoid malignancy. A CTguided transthoracic Tru-Cut (Becton Dickenson and Co., Franklin Lakes, NJ, USA) biopsy indicated B-cell, low grade, lymphoproliferative disease. Microscopic investigation revealed small lymphoid cells with ovoid shape, round nucleus, and narrow cytoplasm. Immunohistochemical results were positive for CD20; however, test for bcl-6, CD23, bcl-1, CD10, CD3, and CD5 were negative (Figure 3). Neoplastic cells stained positive for kappa and negative for lambda. On the basis of clinical, radiological, morphological, and immunohistochemical findings, a diagnosis of pulmonary MZL was made. Bone marrow biopsy showed no lymphoid infiltration and cytogenetic analyses were normal.

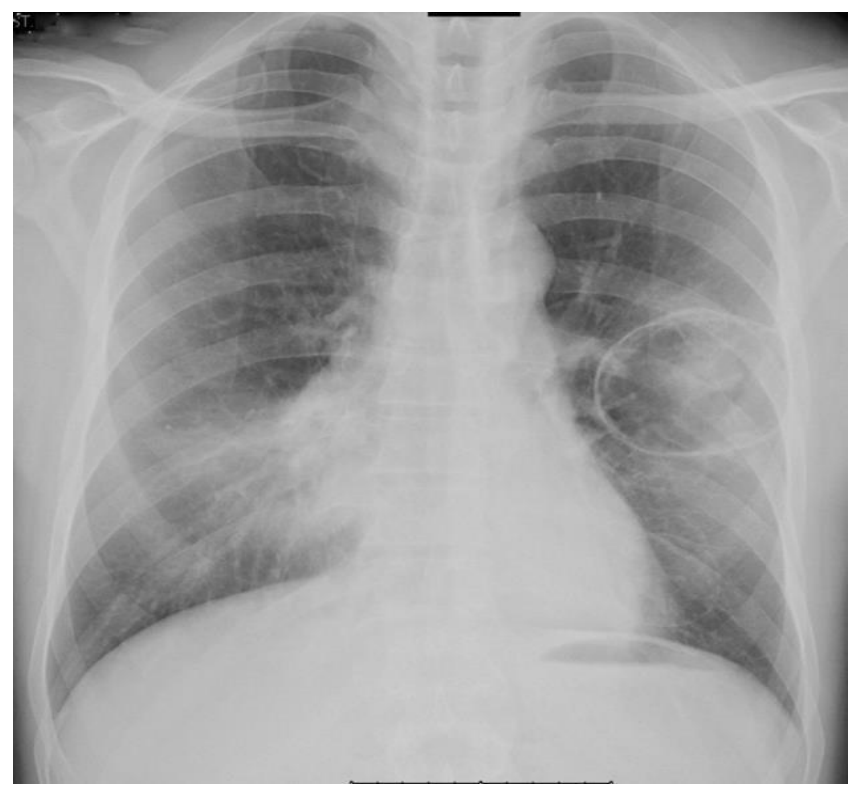

Figure 1: Chest radiograph with a cystic lesion in left middle zone

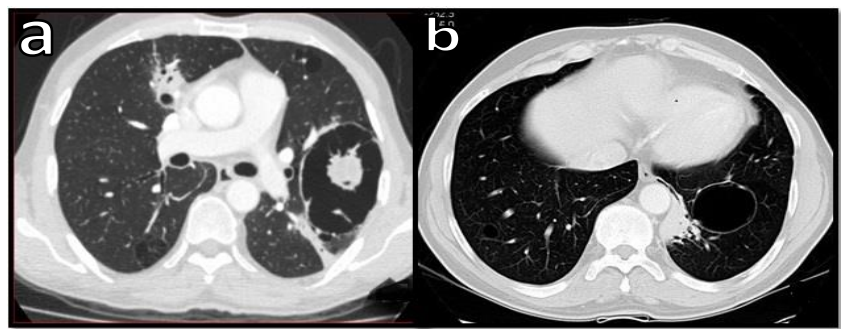

Figure 2: Cystic lesion with a solid component $(9 \mathrm{~cm})$ on CT before treatment (a), after treatment lesion regressed to $4.5 \mathrm{~cm}$ and solid component disappeared (b)

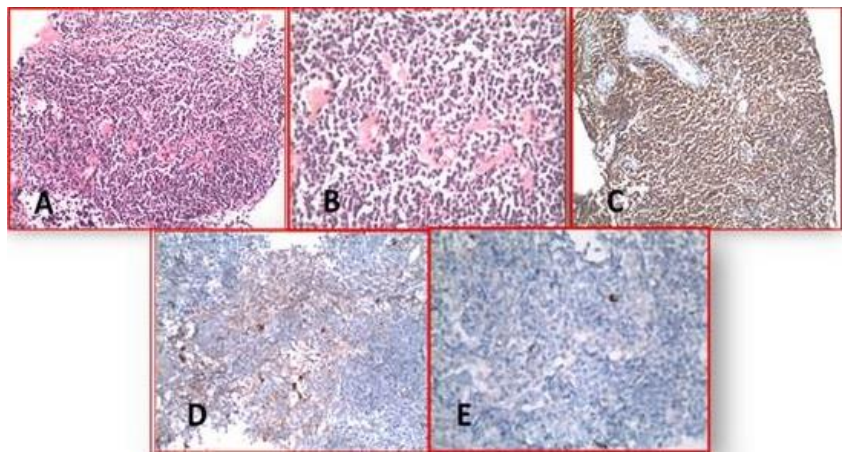

Figure 3: Tumoral tissue with diffuse infiltration (HEx20) (a), lymphoid cells with round nucleus, narrow cytoplasm (HEx40) (b), tumor cells positive for CD20 (x20) (c), focal kappa positivity (x20) (d), tumor cells negative for Lambda staining with rare plasma cells $(x 40)(e)$

Eight cycles of chemotherapy (vincristine + adriamycin + cyclophosphamide + prednisolone) were administered. The cystic lesion did not completely regress, but size decreased from $9 \mathrm{~cm}$ to $4.5 \mathrm{~cm}$. The patient is still in followup. 


\section{DISCUSSION}

Although the lung is a frequent site of secondary involvement of lymphoma, primary lymphoid tumors of the lung are rare. Extranodal marginal zone B-cell lymphoma, a subtype of NHL, is the third most common form of NHL and it accounts for approximately $5 \%$ of $\mathrm{NHL}$ cases (4-6). It is histologically characterized by a heterogeneous cellular composition, including marginal zone or centrocytelike cells, monocytoid B cells, small lymphocytes, and plasma cells (7). It has been reported that MZL is associated with chronic antigenic stimulation, either by autoantigen or pathogen, leading to the accumulation of lymphoid tissue in the involved organs $(8,9)$.

While the gastrointestinal tract is the most common site, approximately $5 \%$ of extranodal MZL is found in the lung $(5,6)$. Extranodal marginal zone B-cell lymphoma can affect any age group of either sex. Patients are generally asymptomatic. It occurs between the ages of 50 and 80 years, with male predominance; our patient was a 52 year-old male. In the largest clinical series, which included 63 patients with primary pulmonary extranodal MZL, the median age was 60 years and $36 \%$ of cases were asymptomatic at time of diagnosis (10). If the patient has symptoms, such as cough, chest pain, or dyspnea, early diagnosis may be possible.

There are few articles related to imaging findings of pulmonary extra nodal MZL. Single or multiple nodules or areas of consolidation constitute the most frequently observed patterns. Multiple or bilateral distribution of the lesions is more common than focal distribution. Groundglass opacity, small centrilobular and branching nodules, and military pattern have also been reported $(11,12)$. In a study that included 21 patients, a single nodular or consolidative pattern was observed in 33\% of patients, multiple nodules or areas of consolidation were observed in $43 \%$ of patients, bronchiectasis and bronchiolitis were observed in $14 \%$ of patients, and diffuse interstitial lung disease was observed in 10\% (11). In another study with 61 patients with primary pulmonary extranodal MZL, lobar or segmental consolidation was detected in $68.9 \%$ of the patients (13). In our case, while there was bilateral, multifocal consolidations, bilateral cystic lesions were also observed, and this radiological pattern is extremely rare. Bronchoscopy may have a limited diagnostic value. In the retrospective analysis reported by $\mathrm{Oh}$ et al. (13), videoassisted thoracoscopic surgery and direct open lobectomy were performed on approximately half of the patients. However, in another series, most of the patients (71.4\%) were diagnosed using minimally invasive procedures, including fiberoptic bronchoscopy, bronchial and transbronchial biopsy, and CT-guided percutaneous transthoracic biopsy (11). In our case, while CT guided transthoracic fine needle aspiration was suspicious for malignan$c y$, the diagnosis was achieved by means of transthoracic needle biopsy. Lymphoid cell proliferation, reactive lymphoid follicles, heterogeneous B cell proliferation, and migration to bronchial epithelium are common histopathological findings (14). Granulomatosis or amyloid deposits and fibrosis are rare. Due to lymphoproliferative cell distribution to the peribronchovascular area, smooth or nodular thickening occurs. Immunohistochemical staining is essential for certain diagnosis. Especially when the biopsy specimen is small, alternatives such as diffuse lymphoid hyperplasia, interstitial lymphoid pneumonia, and follicular bronchitis must be considered (15). Bone marrow involvement is mostly seen with nodal or splenic MZL. Bone marrow biopsy is essential to demonstrate invasion of the disease (16). Our patient's bone marrow biopsy was negative for atypical cells.

Patients with pulmonary MZL have a favorable outcome with a 5 -year overall survival of $>80 \%$. Survival does not differ between gastrointestinal and non-gastrointestinal lymphoma or between localized and disseminated disease $(16,17)$. There is no standard treatment approach for pulmonary MZL. Radiotherapy or surgery can be performed for localized lesions. Typically, CHOP regimen (cyclophosphamide, doxorubicin, vincristine, and prednisone) of chemotherapy is administered (18).

In conclusion, this case was presented as a result of the rare occurrence of pulmonary MZL and extremely rare and unusual radiological pattern of the case.

\section{CONFLICTS OF INTEREST}

None declared.

\section{AUTHOR CONTRIBUTIONS}

Concept - P.A.K., M.Öz, D.K., A.Ç., Ç.A., M.Ö., Ö.Ö.K.; Planning and Design - P.A.K., M.Öz, D.K., A.Ç., Ç.A., M.Ö., Ö.Ö.K.; Supervision - P.A.K., M.Öz, D.K., A.Ç., Ç.A., M.Ö., Ö.Ö.K.; Funding - Ö.Ö.K.; Materials P.A.K., M.Öz; Data Collection and/or Processing - A.Ç., M.Ö.; Analysis and/or Interpretation - Ç.A., A.Ç., D.K.; Literature Review - D.K., P.A.K.; Writing - P.A.K., M.Öz; Critical Review - Ö.Ö.K., M.Ö.

\section{YAZAR KATKILARI}

Fikir - P.A.K., M.Öz, D.K., A.Ç., Ç.A., M.Ö., Ö.Ö.K.; Tasarım ve Dizayn - P.A.K., M.Öz, D.K., A.Ç., Ç.A., 
M.Ö., Ö.Ö.K.; Denetleme - P.A.K., M.Öz, D.K., A.Ç., Ç.A., M.Ö., Ö.Ö.K.; Kaynaklar - Ö.Ö.K.; Malzemeler P.A.K., M.Öz; Veri Toplama ve/veya İşleme - A.Ç., M.Ö.; Analiz ve/veya Yorum - Ç.A., A.Ç., D.K.; Literatür Taraması - D.K., P.A.K.; Yazıyı Yazan - P.A.K., M.Öz; Eleştirel Inceleme - Ö.Ö.K., M.Ö.

\section{REFERENCES}

1. Ferraro P, Trastek VF, Adlakha H, Deschamps C, Allen MS, Pairolero PC. Primary non-Hodgkin's lymphoma of the lung. Ann Thorac Surg 2000; 69:993-7. [CrossRef]

2. Cadranel J, Wislez M, Antoine M. Primary pulmonary lymphoma. Eur Respir J 2002; 20:750-62. [CrossRef]

3. Bektaş SS, Bircan S, Bircan A, Yavuz A, Güneş S, Sırmalı $M$, et al. A Case of extranodal marginal zone lymphoma of the lung: Case report. Turkiye Klinikleri J Med Sci 2012; 32:549-54. [CrossRef]

4. Lu P. Staging and classification of lymphoma. Semin Nucl Med 2005; 35:160-4. [CrossRef]

5. Zucca E, Conconi A, Pedrinis E, Cortelazzo S, Motta T, Gospodarowicz MK, et al. Nongastric marginal zone Bcell lymphoma of mucosa-associated lymphoid tissue. Blood 2003; 101:2489-95. [CrossRef]

6. Arcaini L, Burcheri S, Rossi A, Passamonti F, Paulli $M$, Boveri $E$, et al. Nongastric marginal-zone B-cell MALT lymphoma: prognostic value of disease dissemination. Oncologist 2006; 11:285-91. [CrossRef]

7. Heeren JH, Croonen AM, Pijnenborg JM. Primary extra nodal marginal zone B-cell lymphoma of the female genital tract: a case report and literature review. Int J Gynecol Pathol 2008; 27:243-6. [CrossRef]

8. Royer B, Cazals-Hatem D, Sibilia J, Agbalika F, Cayuela $J M$, Soussi $T$, et al. Lymphomas in patients with Sjogren's syndrome are marginal zone B-cell neoplasms, arise in diverse extranodal and nodal sites, and are not associated with viruses. Blood 1997; 90:766-75.

9. Suarez F, Lortholary $O$, Hermine $O$, Lecuit M. Infectionassociated lymphomas derived from marginal zone $B$ cells: a model of antigen-driven lymphoproliferation. Blood 2006; 107: 3034-44. [CrossRef]

10. Borie R, Wislez M, Thabut G, Antoine M, Rabbat A, Couderc LJ, et al. Clinical characteristics and prognostic factors of pulmonary MALT lymphoma. Eur Respir J 2009; 34:1408-16. [CrossRef]

11. Bae YA, Lee KS, Han J, Ko YH, Kim BT, Chung MJ, et al. Marginal zone B-cell lymphoma of bronchus-associated lymphoid tissue: imaging findings in 21 patients. Chest 2008; 133:433-40. [CrossRef]

12. Abramson JS, Ferry JA, Muse W, Lanuti M. Extranodal marginal zone lymphoma presenting as milliary lung disease. J Clin Oncol 2016; 34:e27-30. [CrossRef]

13. Oh SY, Kim WS, Kim JS, Kim SJ, Kwon HC, Lee DH, et al Pulmonary marginal zone B-cell lymphoma of MALT typewhat is prognostic factor and which is the optimal treatment, operation, or chemotherapy?: Consortium for Improving Survival of Lymphoma (CISL) study. Ann Hematol 2010; 89:563-8. [CrossRef]

14. Yousem SA, Colby TV. Pulmonary lymphomas and lymphoid hyperplasias. In: Knowles DM, ed. Neoplastic Hematopathology. Baltimore, Williams and Wilkins, 1991:979-1007.

15. Addis BJ, Hyjek E, Isaacson PG. Primary pulmonary lymphoma: a re-appraisal of its histogenesis and its relationship to pseudolymphoma and lymphoid interstitial pneumonia. Histopathology 1988; 13:1-17. [CrossRef]

16. Thieblemont C, Berger F, Dumontet C, Moullet I, Bouafia $F$, Felman $P$, et al. Mucosa-associated lymphoid tissue lymphoma is a disseminated disease in one third of 158 patients analyzed. Blood 2000; 95:802-6.

17. Thieblemont C, Bastion Y, Berger F, Rieux C, Salles G, Dumontet $C$, et al. Mucosa-associated lymphoid tissue gastrointestinal and nongastrointestinal lymphoma behavior: analysis of 108 patients. J Clin Oncol 1997; 15:1624-30. [CrossRef]

18. L'Hoste RJ Jr, Filippa DA, Lieberman PH, Bretsky S. Primary pulmonary lymphomas. A clinicopathologic analysis of 36 cases. Cancer 1984; 54:1397-406. [CrossRef] 